\title{
Right To Health Guarantee For Household Workerst
}

\author{
Artika Sophia Maharani' ${ }^{1}$, Wiwik Afifah ${ }^{2}$, Tomy Michael ${ }^{3}$ \\ ${ }^{123}$ Faculty of Law, Universitas 17 Agustus 1945 Surabaya, Semolowaru 45, Surabaya - Indonesia \\ DOI: 10.29322/IJSRP.11.05.2021.p11303 \\ http://dx.doi.org/10.29322/IJSRP.11.05.2021.p11303
}

\begin{abstract}
Lots of Indonesian citizens choose to work as domestic workers due to various factors. In doing their job, many domestic workers work long hours and some don't. It's possible for domestic workers to experience health problems. In Indonesia, there are many employers who don't provide health insurance to domestic workers, resulting in them having to pay for medical treatment themselves without being reimbursed by their employers. Health insurance is one of the rights of domestic workers that they should get. The right to health of domestic workers is not regulated in Law Number 13 of 2003 because domestic workers are considered not to be formal workers but informal workers. From these problems, two problem formulations were drawn, namely first, what is the urgency of regulating health rights for domestic workers. Second, what is the concept of the right to health for domestic workers. The research method used is the type of research using normative legal research the approach uses a statutory, conceptual, and historical approach. The technique of collecting legal materials in this study uses the technique of Inventory, Categorization, and Literature Study. In the research, the results of the first research show that there are urgency factors in regulating health rights for domestic workers, namely philosophical factors that see from the legal ideals found in Pancasila, juridical factors from the articles regulating the right to health for domestic workers, and finally Socio-logical factors see the health problems experienced by domestic workers. Meanwhile, the second research result, namely, the concept of the right to health of domestic workers is one of the most important factors that must be realized by the state through the National Social Security System organized by BPJS Kesehatan. In domestic workers' health, what is meant is physical, spiritual, social health, and not only free from illness, disability and weakness.
\end{abstract}

Index Terms- Insurance, Health, Domestic Workers.

\section{INTRODUCTION}

$I^{n}$ ndonesia is a state based on law. The state has many obligations in fulfilling all the rights which can be called human rights such as the right to health insurance for domestic workers. In fact, the state only regulates the right to health insurance for workers which is regulated by Law No. 13 of 2003, hereinafter referred to as the Manpower Act but doesn't regulate the right to health insurance for domestic workers.

There are economic problems that don't meet the needs of families and the level of education is still low, making a lot of Indonesian people choose to work as domestic workers. They think that the job is a job that is easy for them to get. In addition, there are other problems due to the lack of employment opportunities in the State of Indonesia. So that domestic workers are the only goal to earn a living.

As Indonesian citizens, domestic workers should have the same rights as other people who work in general. There are several regulations, namely in the 1945 Constitution such as article 27 paragraph (2) which states that it guarantees every citizen to get a job and a decent living for humanity, also article $28 \mathrm{D}$ paragraph (2) which states that it provides guarantees for people to work and get fair and proper remuneration and treatment in work relations, and $28 \mathrm{H}$ paragraph (1) which states that every person has the right to live in physical and mental prosperity, to live, to live a good and healthy life and to receive health services, and article 4 of Law Law No. 36 of 2009 concerning Health which states that "everyone has the right to health. ${ }^{(1)}$ However, in reality this regulation is incompatible with workers who have been regulated by Law Number 13 of 2003.

The reason that domestic workers' rights aren't regulated in Law Number 13 of 2003 is because domestic workers aren't considered workers. According to Article 1 point 3 of Law Number 13 Year 2003 which defines the definition of a worker or laborer as follows "everyone who works receives wages or other forms of remuneration". In this article, domestic workers should be classified as workers, but in fact there are several elements that cannot be fulfilled by domestic workers, namely in article 1 point 15 which formulates work relations. The working relationship in question is the relationship between the entrepreneur and the worker or laborer based on a work agreement. In this case the element that cannot be fulfilled is that the employer of the domestic worker isn't an entrepreneur but an individual, the thing that distinguishes an entrepreneur from an employer is that the entrepreneur (business entity) is subject to all standard business obligations under the Law, while the "employer" is only a general obligation to provide "Protection for the welfare of workers, safety and health, both mental and physical (article 35 of Law Number 13 Year 2003) so that domestic workers are included in the scope of work in the non-informal sector, not the informal sector such as factories or companies. In addition, in culture, these domestic workers are considered not as "workers" but only "helpers".

In doing their job, many domestic workers work long hours and some don't. However, it's possible for domestic workers to experience health problems. In Indonesia, there are many employers who don't provide health insurance to domestic workers, resulting in them having to pay for medical treatment themselves without being reimbursed by their employers. Health insurance is one of the rights of domestic workers that they should get. According to the results of the Social Security Survey for Domestic Workers in 2018, as many as 4296 domestic workers 
were organized in 6 cities: $89 \%$ (3823) of domestic workers didn't receive health insurance. ${ }^{(2)}$ In this case it proves that many domestic workers don't get health insurance from their employers.

\section{RESEARCH METHODS}

In this study using normative legal research. ${ }^{(3)}$

\section{DISCUSSION}

\section{The Urgency of Regulating Health Rights for Domestic Workers}

We know that the role of domestic workers in everyday life is very important. The development of the work environment with the times can be said to be more extensive and complex. In carrying out their work, these domestic workers are required to have a lot of skills and expertise such as washing clothes, sweeping, cooking, cleaning, picking up children, caring for children, and so on. There are factors behind the use of domestic workers, including the busyness of the employers in their daily life, laziness in the husband and wife to care for and clean the house, limited time in caring for their children, the wife's lack of cooking skills, and other factors.

In Indonesia, it's also known that until now there are no specific laws and regulations governing domestic workers. With the conditions that occur in domestic workers, there are several problems that are usually faced by domestic workers in Indonesia. These problems include:
a. Poverty
b. Discrimination
c. Low Wages
d. Lack of Standard Working Hours
e. The Occurence of Violence
f. Restrictions on Freedom and Access to Information
g. The absence of a domestic worker organization
h. The absence of Social Security, Health Insurance and Other Benefits

From the events described above, it can be said that this domestic worker has never been paid attention to by the government in it's history at all. However, in these rights which are stated in the Permenaker, there is no regulation regarding the right to health insurance for domestic workers. Therefore this Permenaker is said not to become a legal umbrella for domestic workers. In addition, Ministerial Regulations certainly lack legal force when compared to laws. Until now, the legal status of domestic workers is still the status of ius constitutum, where the PRT bill hasn't been recognized and passed by the state. In fact, the PRT Bill has been proposed since 2004 and has been included in the National Legislation Program (Prolegnas) several times but hasn't been discussed by the members of the council to date. The obstacle for not passing the Domestic Workers Bill immediately lies in the policyholders. There are DPR members who are public officials and stakeholders, many of whom are all employers. ${ }^{(4)}$ Of course this is an obstacle because the PRT Bill is a bill that employers do not want. The absence of guaranteed legal protection for domestic workers is a form of injustice experienced by domestic workers. This justice is the spirit of the law itself. In the context of the welfare state, legal protection for domestic workers is intended as a form of state responsibility in an effort to respect, protect and fulfill the basic rights of all citizens. Indonesia as a welfare (law) country, of course, also has the obligation to respect, protect and fulfill the basic rights of all citizens without exception, including the basic rights of domestic workers. ${ }^{(5)}$ In Blackett's view, the special regulation for domestic workers is the key to protecting their rights by arguing that, the special regulation will provide recognition that domestic workers are involved in an employment relationship and there is recognition that domestic workers also contribute to the economy.

With the absence of recognition of the Draft Domestic Worker Bill, domestic workers haven't received legal protection for all their rights, including the right to health insurance for domestic workers and they don't have access to protection in case of a dispute between the employer and the domestic worker. In addition, it causes employers to act arbitrarily towards their domestic workers, such as not providing health insurance for domestic workers. From this consequence, the PRT Bill should be passed immediately so that all domestic workers can enjoy all their rights. From philosophical factors, the basis for the collective values of the national collection as stated in the Pancasila principles is the foundation that must be found in Indonesian law. National collective values are the ideals of Pancasila law which are understood as thoughts in the form of an obligation to direct the law in accordance with what the community wants, including domestic workers. The wishes of domestic workers are in accordance with the rights of domestic workers that should be obtained in the form of : Right to wages, Right to work restrictions, Right to information on types of work, Right to get time off, Right to leave, Right to occupational safety and health, Right to social security, Right to freedom of association.

In the opinion of Gustav Radbruch, defines the function of legal ideals as a measure that is regulative and constructive, so that without legal ideals there is no meaning in a legal product. ${ }^{(6)}$ Legislation, especially regarding the right to health, can be said to have a philosophical basis, if there is justification that is studied philosophically in each of its formulations or norms. This means that the formulation and norms get reasons in accordance with the ideals and views of life in society and according to the ideals of truth, justice, the nation's philosophy of life, and morality. ${ }^{(7)}$

The formation of laws and regulations, especially regarding health insurance, is a process of embodying the values contained in the ideals of law into legal norms, so it really depends on the level of awareness and appreciation of the legislators. Lack of awareness and appreciation of these values can result in gaps between legal ideals and legal norms. The Republic of Indonesia is a country that has the ideals of Pancasila law as well as the fundamental norms of the state, so every regulation contained therein must have values that embody these legal ideals, namely Pancasila.

The juridical factor is an important factor in the urgency of regulating the right to health insurance for domestic workers. It's said to be important because it relates to the role of law in development, both as a regulator of behavior to solve problems. With the provision of regulations on domestic workers, especially for domestic workers' health insurance, domestic workers will receive legal protection to ensure certainty and justice in fulfilling their right to health insurance. This legal protection is a protection 
using legal means that aim to provide shelter in protecting the rights of citizens called Human Rights which have been harmed by others.(8) According to Giwo Rubianto's opinion in a webinar with the theme of Commemorating International Domestic Workers Day, he stated that domestic workers shouldn't be left behind in the development of Indonesian human resources. If foreign workers are given protection, domestic workers should also receive justice and protection.

We know that many Indonesian citizens work as domestic workers. This is due to various factors, namely inadequate economic needs, low levels of education, and lack of employment opportunities, most Indonesians choose domestic workers as jobs that are easily available. According to data from the Central Bureau of Statistics (BPS), the number of domestic workers in Indonesia is estimated to be 4 million, and around 85 thousand are children under 18 years of age, while $95 \%$ are female. ${ }^{(9)}$ The estimated number of domestic workers increases by an average of $1.4 \%$ every year and they are very vulnerable to incidents of exploitation and violence because most of them are women. As of December 2017, the Legal Aid Institute for Domestic Workers Advocacy Network noted that 249 cases of domestic workers occurred in Indonesia, including : violence, rape, complaints of unpaid wages, layoffs before Hari Raya, THR that weren't paid by employers and rights for health insurance that is not fulfilled by the employer.

The scope of work of domestic workers in the domestic sphere makes community culture considered a private domain, thus causing any violence perpetrated by the employer/employer's family and/or whatever treatment is done to domestic workers, is considered a family problem, so that outsiders may not interfere or even become involved in the affair. This has resulted in a phenomenon that occurs to domestic workers due to the actions of their employers or their employers' family, which is like an "iceberg", meaning that the number of those who experience violence can certainly be greater than what the public knows.

Legal awareness in society that has been built based on the value of patriarchy, with the public-domestic dichotomy is considered not as a job, has implications for domestic workers who are actually women. The kinship relationship that has been built in the reality between employers and domestic workers has further confirmed the legal awareness of the community about the insignificance of the rule of law for domestic workers. Public legal awareness regarding legal regulations that provide protection guarantees for domestic workers, especially regarding health insurance, further affects the process of drafting Law Number 13 of 2003, as well as a special law on protection of domestic workers, especially health insurance, which until now has not received protection. According to Warrasih, he argues that the implementation of legal products is carried out with three hopes, namely the sociological stage, the political stage and the juridical stage. At the sociological stage, it's determined by legal materials that exist in the reality of society. That is, the emergence of social problems or problems is the result of society itself. This problem will only become a policy problem, if it raises public awareness to deal with these problems. Therefore, of the many cases that have befallen domestic workers so far, it will not become a policy problem or public agenda because there are still many people who don't have awareness of the importance associated with problems that occur in domestic workers, especially health insurance. ${ }^{(10)}$

\section{THE CONCEPT OF THE Right TO HEALTH FOR DOMESTIC WORKERS}

In terms of health itself, according to WHO, health is a dynamic condition in humans consisting of physical, spiritual, social health, and not only free from diseases, disabilities, and weaknesses. ${ }^{(11)}$ Said to be physically healthy means that the person doesn't have any disturbance in his body, which means that all his organs can function properly and he isn't sick. There was a case of someone who said he was sick or not feeling well and then that person went to a doctor. From the results of the doctor's examination, he said that the person was not sick, this could be because the person actually had a mental/psychological disorder that affected his mental state. There are examples of people who are mentally healthy aren't autistic, don't experience stress, don't experience acute mental disorders, don't have problems with mental disorders such as kleptomania, psychopaths, and others. Meanwhile, said to be socially healthy is the ability of a person to interact with the environment in which he lives. An example of a person who isn't mentally healthy is a prostitute woman. ${ }^{(12)}$

From this understanding, to make health a human right, the state must provide all Indonesian citizens with various health efforts through the implementation of quality health development and affordable to all Indonesian citizens. This health can be called a pillar of the development of a nation. Health can also be said as one of the basic human needs that must be met. Health is said to be important because health is everything, without health everything is meaningless. The point is that this health is the primary need of every human being. The healthy condition of body and soul experienced by every human being will enable humans to carry out all their activities and works very well. Health is part of the need for a prosperous life. Basic rights in general and rights in health services in particular can be differentiated into social basic rights and individual basic rights. ${ }^{(13)}$

In the definition of health services, there are several expert opinions that explain that according to Wiku Adisamita, health services are all methods made by individuals or collectively in an organization with the aim of maintaining and improving health, preventing and treating disease and restoring the health of individuals, groups or communities. ${ }^{(14)}$ Meanwhile, according to Benyamin Lumenta, stated that health services are various ways and activities to prevent and treat diseases, all efforts and activities to improve and restore health are carried out on the basis of individual relationships between medical service experts and individuals in need. ${ }^{(15)}$

The provision of health services in fulfilling the right to health is part of the responsibility of the state. This has been regulated by the 1945 Constitution in article 34 paragraph (3) which states that the State is responsible for the provision of health services. The responsibility referred to is described in article 15 of Law Number 36 Year 2009, namely the responsibility for the availability of the environment, structure, health facilities, both physical and social, for the community to achieve the highest health status. Meanwhile, Article 16 of Law Number 36 Year 2009 describes the responsibility in the form of providing resources in the health sector that are fair and equitable for all people to obtain the highest health status. 
In realizing the responsibility for providing health services, the state provides social security to all Indonesian people. The definition of social security is part of the obligations and responsibilities of the state in providing socio-economic protection for the community. In accordance with the condition of Indonesia's financial capacity as a developing country, it has begun to develop social security programs based on funded social security, namely social security that is funded by participants and is still limited to the formal sector community. ${ }^{(16)}$ This social security is a part of human rights that must be realized by the government through the national social security system or commonly known as SJSN. This social security system is governed by statutory regulations, namely Law Number 40 of 2004 concerning SJSN. This regulation is made based on 3 (three), namely the principle of humanity, the principle of benefit, and the principle of social justice as described in article 2 (two). The three principles are intended to ensure the continuity of the program and the rights of participants ${ }^{(17)}$

The right to health of domestic workers ${ }^{(18)}$ shouldn't only be obtained from health insurance through the government program with the category of contribution assistance recipients (PBI), the rights to health of domestic workers are also obtained from the employers who employ these domestic workers. Employers should provide social security in the form of labor rights and in particular health rights to domestic workers by registering domestic workers and their families in a social security program that isn't PBI. However, in reality, many employers don't enroll their domestic workers in the social security program through the BPJS. This is due to the weak position of domestic workers due to the existence of an oral agreement without any witnesses hearing the agreement apart from the absence of specific laws and regulations regarding domestic worker health insurance. From this it should be an evaluation of the government to conduct outreach to informal workers, especially domestic workers, so that domestic workers who aren't registered with the social security program registered by their employer can register themselves as contributory beneficiary participants (PBI), then they can be free from the fees charged in every month.

Meanwhile, if there is a household that employs more than 10 domestic workers, these employers shouldn't only provide health insurance but also provide employment security which is included in the social security category. This is explained by Government Regulation Number 84 of 2013 concerning the Administrators of the Workforce Social Security Program. Employment security which is meant to be in the form of work accident insurance, life insurance, and old age insurance.

The right to obtain information regarding health in question includes: ${ }^{(19)}$

1) Diseases suffered by domestic workers;

2) What medical measures to be taken to domestic workers;

3) Possible complications as a result of these measures and actions to overcome them;

4) Other therapeutic alternatives that can be done by PRT;

5) Prognosis, and

6) Estimated cost of domestic workers treatment.

Apart from the right to obtain information about health, this domestic worker has the right to receive protection from violence. Where we know that there are many cases that have occurred in
Indonesia regarding violence perpetrated by employers against their domestic workers. Violence in question is both physical and verbal violence. The physical violence referred to is kicking domestic workers, pouring hot water, hitting domestic workers, and so on. Meanwhile, the verbal violence referred to is about the employer speaking offensive language to the domestic workers. Therefore, the right to get protection from violence is one that must be fulfilled in the health rights of domestic workers.

From all that has been explained about the right to health of domestic workers above, the right to health in question that should be obtained by domestic workers is the right to obtain health insurance such as BPJS Kesehatan, the right to obtain information about health, and the right to get protection from domestic violence. This right to health is one that must be protected and fulfilled. The form of protection for the health rights of domestic workers is that the bill of domestic workers is immediately passed so that all the health rights of domestic workers are protected and that the health of the domestic workers is guaranteed. So, in this case, domestic workers should have the right to health and domestic workers or employers should provide health insurance to their domestic workers.

\section{CONCLUSION}

Based on the discussion that has been explained above, the authors draw the conclusion that from the several problems experienced by domestic workers, especially regarding the absence of health insurance that domestic workers should get, then there should be regulations that regulate the right to health insurance for domestic workers. There are urgent factors in regulating the right to health insurance for domestic workers, namely : First, philosophical factors. From philosophical factors, the basis for the collective values of the national collection as stated in the Pancasila principles is the foundation that must be found in Indonesian law.

\section{Ethical Clearance}

This research was approved by the ethical of Universitas 17 Agustus 1945 Surabaya. Before participation on the research process, all participants signed an informed consent and all the interest of all participants are secured.

\section{Source of Funding: self}

\section{Conflict of Interest: none declared}

\section{REFERENCES}

[1] 1. Revita Pirena Putri, Wiwik Afifah TM. POVERTY AS A BARRIER TO THE ACHIEVEMENT OF THE RIGHT TO HEALTH. Int $J$ Soc POLICY LAW. 2(1):103-8.

[2] 2. Adhitya dan Lili. Derita PRT Mulai Dari PHK Hingga Upah Dan THR Tidak Dibayar. 2018.

[3] 3. Michael T. KAJIAN KRITIS TERHADAP RANCANGAN PERATURAN WALIKOTA SURABAYA TENTANG TATA CARA PENERBITAN IZIN PENYELENGGARAAN PARKIR DI LUAR RUANG MILIK JALAN. J Huk Bisnis Bonum Commune. 2019;

[4] 4. Darji S. Pokok-Pokok Filsafat Hukum, Apa dan Bagaimana Filsafat Hukum Indonesia. PT. Gramedia Pustaka Utama; 2006. 
[5] 5. Sofiani T. Perlindungan Hukum Pekerja Rumah Tangga Berbasis Hak Konstitusional. Yogyakarta: Deepublish; 2020.

[6] 6. Radbruch G. Five minutes of legal philosophy (1945). Oxf J Leg Stud. 2006;

[7] 7. MORALS AND SOCIETY IN ZOROASTRIAN PHILOSOPHY. In: Companion Encyclopedia of Asian Philosophy. 2020.

[8] 8. Harliza ER, Michael T. PENEGAKAN HUKUM ILLEGAL FISHING. Mimb Keadilan. 2020;

[9] 9. Oebaidillah S. 16 Tahun RUU Perlindungan Pekerja Rumah Tangga Belum Disahkan. 2020.

[10] 10. Harrison EA, Wu JW. Vaccine confidence in the time of COVID-19. Eur J Epidemiol. 2020;

[11] 11. Parvanta CF, Bass SB. Health communication: strategies and skills for a new era. Healt communication: strategies and skills for new era. 2020.

[12] 12. Rock P. Caesare Lombroso as a signal criminologist. Criminology and Criminal Justice. 2007.

[13] 13. Fredy Tengker. Hak Pasien. Bandung: Mandar Maju; 2007.

[14] 14. Wiku Adisasmita. Sistem Kesehatan. Jakarta: Rajawali Press; 2010.

[15] 15. Benyamin Lumenta. Pelayanan Medis. Yogyakarta: Kamisius; 1987.
[16] 16. Agusmidah. Dinamika Dan Kajian Teori Hukum Ketenagakerjaan Indonesia. Bogor: Ghalia Indonesia; 2010.

[17] 17. DJSN. Asas, Tujuan, dan Prinsip SJSN. 2020.

[18] 18. World Health Organization. Personal, domestic and community hygiene. Healthy Villagers: A Guide for Communities and Community Health Workers. 2019.

[19] 19. Rahmia Rachman. Hak Pasien Atas Informasi Penerapannya Dalam Kasus Prita Mulyasari. Universitas Airlangga; 2010.

\section{AUTHORS}

First Author - Artika Sophia Maharani, Faculty of Law, Universitas 17 Agustus 1945 Surabaya, Semolowaru 45,

Surabaya - Indonesia

Second Author - Wiwik Afifah, Faculty of Law, Universitas 17 Agustus 1945 Surabaya, S

Third Author - Tomy Michael, Faculty of Law, Universitas 17 Agustus 1945 Surabaya, S 